УДК 632.955: 634.7

DOI: 10.30679 / 2219-5335-2018-2-50-148-168

ВЫЯВЛЕНИЕ УСТОЙЧИВЫХ К ДИТИЛЕНХОЗУ

СЕЛЬСКОХОЗЯЙСТВЕННЫХ КУЛЬТУР, ОБЕСПЕЧИВАЮЩИХ РЕАЛИЗАЦИЮ ПРОДУКЦИОННОГО И АДАПТИВНОГО ПОТЕНЦИАЛА НАСАЖДЕНИЙ ЗЕМЛЯНИКИ

Холод Надежда Афанасьевна канд. биол. наук, доцент старший научный сотрудник лаборатории защиты плодовых и ягодных культур

Федеральное государственное бюджетное научное учреждение «Северо-Кавказский федеральный научныи йентр садоводства, виноградарства, виноделия», Краснодар, Россия

Дитиленхоз, вызываемый стеблевой нематодой Ditylenchus dipsaci, является особо опасным заболеванием земляники в Южном регионе России. Болезнь распространена на промышленных плантациях, в фермерских и подсобных хозяйствах региона, а также в селекционных коллекциях Майкопской ОСС ВИР. В зоне деятельности СКФНЦСВВ промышленные плантации земляники свободны от дитиленхоза уже более тридцати лет. Целью наших исследований является выявление устойчивых к стеблевой нематоде видов сельскохозяйственных культур, обеспечивающих продукционный и адаптивный потенциал землянике садовой. В статье приводятся данные по влиянию различных видов растений на земляничного дитиленха и выявлению устойчивых к стеблевой нематоде сельскохозяйственных культур. Изучено 29 видов сельскохозяйственных культур, отмечена инвазия практически всех видов растений в молодом возрасте, за исключением пшеницы мягкой
UDC 632.955: 634.7

DOI: 10.30679 / 2219-5335-2018-2-50-148-168

\section{REVEALING OF AGRICULTURAL CROPS TOLERANT TO DITILENHUZ, ENSURING THE REALISATION OF PRODUCTIVE AND ADAPTIVE POTENTIAL OF STROWBERRY ORCHARDS}

\author{
Holod Nadezhda Afanasyevna \\ Cand. Biol. Sci., Docent \\ Senior Research Associate \\ of Laboratory of the Fruit \\ and Berry crops Protection

\section{Federal State Budget \\ Scientific Institution \\ "North Caucasian Federal \\ Scientific Center of Horticulture, Viticulture, Wine-making", Krasnodar, Russia}

Ditilenchus, caused by the stem nematode Ditylenchus dipsaci, is a particularly dangerous disease of strawberry in the Southern Region of Russia. The disease is common on industrial plantations, in farmer and subsidiary farms of the region, as well as in the breeding collections of the Maikop experimental station. In the area of activity of the NCFSCHVW, industrial plantations of strawberry are free from ditilenchus for more than thirty years. The purpose of our research is to identify the resistant to the stem nematode of species of agricultural crops provided the production and adaptive potential of strawberry garden. The article presents data on the influence of various plant species strawberry ditilenchus and the identification of resistant crops to stem nematodes. 29 kinds of agricultural crops were studied, an invasion of almost all plant species at a young age was noted, with the exception of soft wheat 
и рассады томата и капусты.

Появление симптомов поражения у земляники садовой проявлялось не ранее, чем через 4-6 недель после инокуляции.

Полученные нами результаты

подтверждают установленные зарубежными исследователями данные, что стеблевая нематода способна на фоне сильного заражения почвы причинять существенный ущерб видам растений, независимо от того, поддерживают те, или нет размножение соответствующих рас дитиленхов. Установлено: лук, гречиха, горох, овес, в несколько меньшей степени пасленовые и зонтичные (кроме моркови), оказались по восприимчивости к стеблевой нематоде близкими к землянике садовой по обоим показателям. Тыквенные, люцерна, клевер красный отнесены к невыносливым культурам, без поддержания размножения паразита. Пшеница, ячмень, кукуруза, свекла, капуста, морковь, редис проявили устойчивость к дитиленхозу, и эти культуры могут способствовать повышению продукционного и адаптивного потенциала земляники садовой.

Ключевые слова: ЗЕМЛЯНИКА САДОВАЯ, ДИТИЛЕНХОЗ, ВРЕДОНОСНОСТЬ, СИМПТОМЫ ПОРАЖЕНИЯ, СЕЛЬСКОХОЗКУЛЬТУРЫ and tomato and cabbage seedlings.

The appearance of symptoms of strawberry defeat is shown no earlier than 4-6 weeks after inoculation. Our obtained results confirm the data of foreign research that the stem nematode is capable to cause significant damage to plant species under the condictions of significant soil contamination, regardless of whether they contribute the reproduction of the corresponding races of ditilenchus. It is established: onion, buckwheat, peas, oats, to a lesser extent solanaceous and umbrella crops (except carrots), were susceptible to stem nematode close to strawberry on both indicators. Pumpkin, alfalfa and red clover are non-tolerant crops, without maintaining the reproduction of the parasite. Wheat, barley, corn, beet, cabbage, carrots, radish have shown the resistance to ditilenchus, and these crops can contribute to increase in the productive and adaptive potential of strawberry.

Key words: STRAWBERRY GARDEN, DITILENHUS, HARMFULLNESS, SYMPTOMS OF LOSS, AGRICULTURAL CROPS

Введение. Дитиленхоз, вызываемый стеблевой нематодой Ditylenchus dipsaci (Kuhn, 1857, Filipjev, 1936) является особо опасным заболеванием в южном регионе. Болезнь распространена на промышленных плантациях, в фермерских и подсобных хозяйствах Краснодарского и Ставропольского краев, Ростовской области и Республики Адыгея, в селекционных коллекциях Майкопской ОСС ВИР. В зоне деятельности СКФНЦСВВ промышленные плантации свободны от дитиленхоза уже более тридцати лет. Убытки от стеблевой нематоды достигают 250 тысяч рублей на гектар и более. 
Изреженность плантаций достигает такого уровня, что их приходится запахивать на второй год после посадки [1].

Высокая вредоносность дитиленхоза, в основном, связана с использованием не оздоровленной рассады, неупорядоченностью севооборотов и отсутствием пестицидов.

Для снижения вредоносности стеблевой нематоды на землянике садовой в современных условиях единственным мероприятием, снижающим вредоносность паразита, является использование устойчивых к нему сельскохозяйственных культур в земляничных севооборотах.

Целью наших исследований является выявление устойчивых к стеблевой нематоде видов сельскохозяйственных культур, обеспечивающих продукционный и адаптивный потенциал землянике садовой.

Объекты и методы исследований. Объектами изучения являлись растения земляники садовой, 29 видов сельскохозяйственных культур и стеблевая нематода $D$. dipsaci. Исследования проведены в прикубанской зоне Краснодарского края. Обследования земляничных насаждений проведены в хозяйствах Краснодарского и Ставропольского краев, Ростовской области и Республики Адыгея.

Насаждения земляники садовой на наличие D. dipsaci обследовались равномерно - челночным способом с вычленением классов зараженности площадей $[2,3]$. Расчет численности нематод проводили по 3 субобразцам листвы из средних проб в 100-200 г листьев, рендомизированно отбиравшихся на плантации.

Полевые наблюдения проводили в посевах и посадках, размещенных на полях, в предшествующие годы занятых зараженной дитиленхозом земляникой, очаги поражения которых в соответствующее время картировали. 


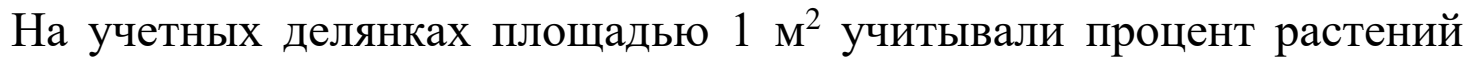
каждого культурного вида с симптомами D. dipsaci в 3-кратной повторности. Анализировали субобразцы в 5-10 г растительной массы, полученные из сборных средних проб весом 50-200 г каждая, вороночным методом или прямым микроскопированием расщепленных галлов [3-4].

При изучении влияния различных сельскохозяйственных культур на земляничного дитиленха в вегетационных опытах сосуды емкостью 10 литров заполняли свободной от $D$. dipsaci черноземной среднесуглинистой почвой $[5,6,7]$. Перед высевом семян в нее заделывали зараженные дитиленхозные листья земляники садовой с известной численностью D. dipsaci с тем, чтобы обеспечить наличие 1000-1200 особей на сосуд. После этого проводили посев наклюнувшихся безнематодных семян сельскохозяйственных культур.

Эталонами служили безнематодные розетки земляники садовой сорта Зенга Зенгана и черный пар. Для создания благоприятных условий для инвазии растений сосуды с увлажненной почвой в течение 3 суток выдерживали при температуре $+15 \ldots+20^{\circ} \mathrm{C}$, после чего сосуды вкапывали на $4 / 5$ в грунт на экспериментальном участке в ОПХ «Центральное» и проводили исследования вплоть до уборки урожая культуры. Повторность каждого варианта была 8-кратной. Температуру и влажность воздуха регистрировали с помощью термографа М-16 АН и гигрографа.

В ходе проведенных нами опытов (через 2-3 недели после появления всходов и при уборке) учитывали: процент растений с симптомами $D$. dip$s a c i$; численность дитиленхов и наличие их яиц в тканях в те же сроки (в пересчете на г растительной массы из 3 выборок в 5-10 г на каждый сосуд). Нематод выделяли вороночным методом и прямым микроскопированием расщепленных тканей; определяли высоту и вес 10 пораженных и 10 внешне здоровых растений каждой культуры $[8,9]$. 
Плодоводство и виноградарство Юга России № 50(02), 2018 г.

После уборки соответствующих культур осенью того же года в половину сосудов высаживали по 3 безнематодных растения земляники сорта Зенга Зенгана, другую половину засаживали аналогичным образом весной следующего года. Растения выращивали вплоть до уборки урожая, определяя вес и количество ягод, процент заражения, силу поражения дитиленхозом в баллах по 5-балльной шкале и содержание в них дитиленхов.

Учеты поражения различных видов растений по симптомам (в \%), по численности дитиленхов и их яиц во внешне здоровых и пораженных растениях проводили не менее 2 раз за вегетационный период [4].

По окончании опытов рассчитывали: коэффициент размножения дитиленхов при уборке сельскохозяйственных растений относительно плотности их популяции в фазу всходов; редукцию высоты пораженных растений относительно здоровых и индекс вегетативной вредоносности стеблевой нематоды, равный произведению потери веса (в \%) больных растений по отношению к здоровым. При сопоставлении результатов всех опытов каждый вид растений классифицировали по шкале [4, 10].

Обсужнение результатов. При изучении влияния 29 сельскохозяйственных культур на земляничного дитиленха реакцию растений оценивали по комплексу показателей. Отмечена инвазия практически всех видов сельскохозяйственных растений в молодом возрасте, за исключением пшеницы мягкой и рассады (но не семенных проростков) томата и капусты $[8,9]$.

Симптомы поражения у молодых растений сельскохозяйственных культур в целом соответствовали известным в литературе описаниям [11, 12 и др.]. Они представлены в табл. 1 и на рис. 1 и 2. Это подтверждает выдвигаемое в последние годы положение об отсутствии иммунных к инвазии D. dipsaci растений и малой вероятности выявления враждебных для этого вида нематод сельскохозяйственных культур, включая и известные своей нематицидностью бархатцы [2, 3, 9, 13-15 и др.]. 
Плодоводство и виноградарство Юга России № 50(02), 2018 г.

В зрелом возрасте, однако, симптомы поражения сохранялись далеко не у всех видов культур и, главное, формировавшиеся после стадии всходов органы растений не несли признаков поражения, помимо земляники садовой. Симптомы поражения у нее полностью проявлялись не ранее, чем через 4-6 недель после инокуляции. Усиление симптомов с возрастом растений имело место у лука и не во все годы у сельдерея, пастернака, перца, картофеля, баклажана и томата (семенами) (рис. 3-9).

Резкое ослабление симптомов к моменту уборки имело место у кабачка, арбуза, укропа, гороха, сои, чеснока, подсолнечника. Почти не заражались и быстро оправлялись от признаков болезни кукуруза, свекла, редис и, особенно, морковь (рис. 3, 4).

Однако, следует отметить, что у большинства видов сельскохозяйственных культур, наиболее сильно пораженных в фазе всходов, растения так и не оправлялись от ущерба к моменту уборки, не росли и практически не давали урожая. Вегетативная продуктивность снижалась более чем на 50\% у огурца, укропа и овса в среднем за 3 года, у гороха, перца, сои, картофеля, баклажана, лука и люцерны - за 2 года (рис. 5-9).

Несколько меньшим ущерб был для кабачка, петрушки, томата, отсутствовал или был мало ощутимым в случае пшеницы, капусты, моркови, свеклы, кукурузы, редиса.

Полученные результаты подтверждают установленные за рубежом данные, что расы D. dipsaci способны на фоне сильного заражения почвы причинять существенный ущерб видам растений, независимо от того, поддерживают те или нет размножение стеблевой нематоды [13-15]. Разумеется, в условиях вегетационных опытов фон заражения был очень интенсивным и равномерным, чего не наблюдается в полевых условиях, поэтому процент заражения растений был завышенным. 
Плодоводство и виноградарство Юга России № 50(02), 2018 г.

Основные типы симптомов дитиленхоза у различных видов сельскохозяйственных растений

\begin{tabular}{|c|c|c|c|c|c|c|c|c|c|c|}
\hline \multirow[b]{2}{*}{ Культура } & $\begin{array}{c}\text { Утолще } \\
\text { ния } \\
\end{array}$ & $\begin{array}{c}\text { Искрив- } \\
\text { ления }\end{array}$ & \multirow{3}{*}{$\begin{array}{c}\text { Тюльпа- } \\
\text { новый } \\
\text { корень- } \\
\text { «вспучи- } \\
\text { вание» }\end{array}$} & $\begin{array}{l}\text { Морщи- } \\
\text { нистость }\end{array}$ & $\begin{array}{c}\text { Деформа- } \\
\text { ция }\end{array}$ & \multicolumn{2}{|c|}{ Хлоротичность } & \multirow{2}{*}{$\begin{array}{c}\text { Угнете- } \\
\text { ние } \\
\text { роста }\end{array}$} & \multirow{2}{*}{$\begin{array}{c}\text { Наличие } \\
\text { урожая }\end{array}$} & \multirow{2}{*}{$\begin{array}{c}\text { Регене- } \\
\text { рация }\end{array}$} \\
\hline & \multicolumn{2}{|c|}{ осевых органов } & & \multicolumn{2}{|c|}{ листовых пластинок } & $\begin{array}{c}\text { семядо- } \\
\text { лей }\end{array}$ & листьев & & & \\
\hline 1 & 2 & 3 & & 5 & 6 & 7 & 8 & 9 & 10 & 11 \\
\hline Овес & ++ & - & ++ & - & - & - & + & ++ & - & - \\
\hline Кукуруза & + & - & + & - & + & - & + & + & + & + \\
\hline Подсолнечник & ++ & + & - & - & + & - & & - & + & + \\
\hline Лук & + & - & ++ & - & - & - & + & + & - & + \\
\hline Чеснок & & - & + & - & - & - & - & - & - & - \\
\hline Томат & ++ & + & - & - & - & - & - & ++ & - & - \\
\hline Картофель & + & + & - & ++ & + & - & - & - & - & - \\
\hline Перец & + & - & - & ++ & + & - & + & + & - & - \\
\hline Баклажан & + & - & - & ++ & + & - & - & ++ & - & - \\
\hline Гopox & + & - & - & + & - & - & - & + & - & - \\
\hline Соя & ++ & + & - & ++ & - & - & - & ++ & - & - \\
\hline Люцерна & + & - & - & - & - & - & - & ++ & - & - \\
\hline
\end{tabular}


Плодоводство и виноградарство Юга России № 50(02), 2018 г.

\section{Продолжение таблицы}

\begin{tabular}{|c|c|c|c|c|c|c|c|c|c|c|}
\hline 1 & 2 & 3 & 4 & 5 & 6 & 7 & 8 & 9 & 10 & 11 \\
\hline Клевер & + & - & - & - & - & - & - & + & - & - \\
\hline Морковь & + & - & - & - & - & - & - & - & - & ++ \\
\hline Капуста & + & - & - & - & - & - & - & + & - & + \\
\hline Свекла столовая & + & + & - & - & + & - & - & + & - & + \\
\hline Салат & + & - & - & + & + & - & - & + & - & + \\
\hline Укроп & + & - & - & - & - & $\begin{array}{ll}- \\
-\end{array}$ & - & - & - & + \\
\hline Петрушка & + & - & - & - & - & - & - & + & - & ++ \\
\hline Пастернак & + & - & - & + & - & - & - & + & - & - \\
\hline Сельдерей & +- & - & - & - & - & - & + & + & - & + \\
\hline Арбуз & + & - & - & - & - & $\begin{array}{ll}- \\
-\end{array}$ & - & + & - & + \\
\hline Огурец & + & - & - & - & + & + & - & + & - & + \\
\hline Кабачок & + & - & - & + & + & + & - & + & - & + \\
\hline
\end{tabular}

Условные обозначения: - = нет; + = умеренно; ++ = сильно 
Плодоводство и виноградарство Юга России № 50(02), 2018 г.

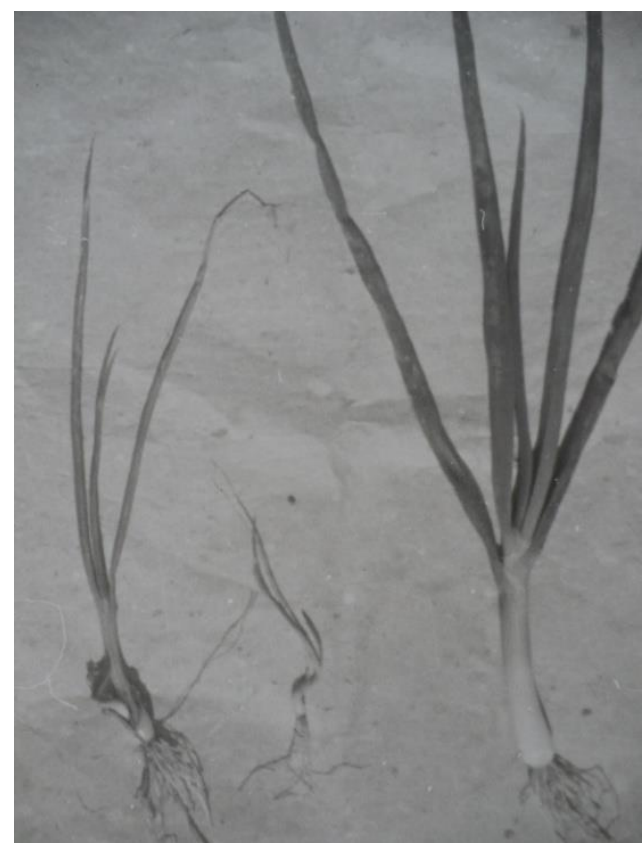

Лук

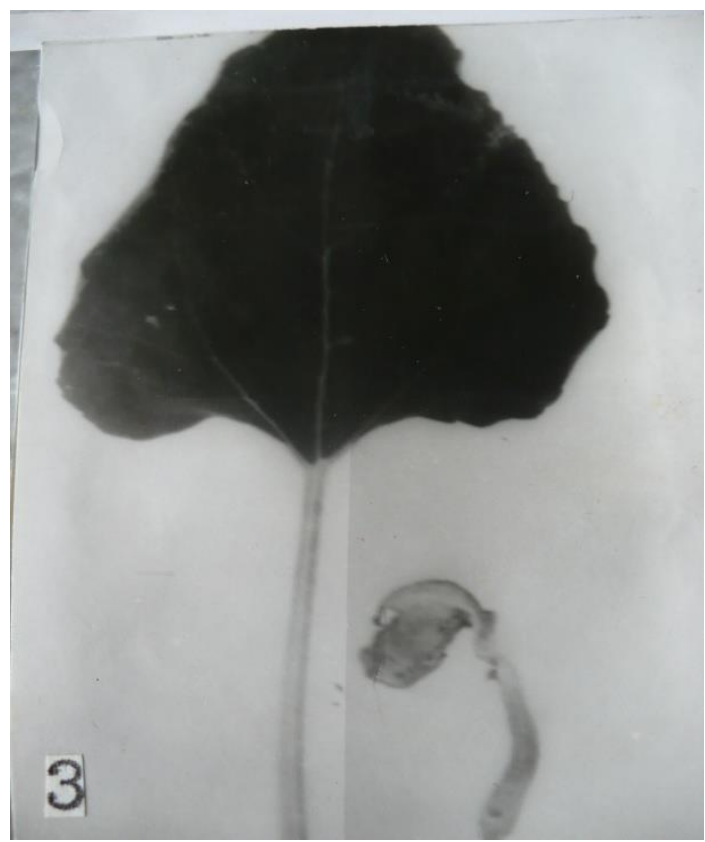

Подсолнечник

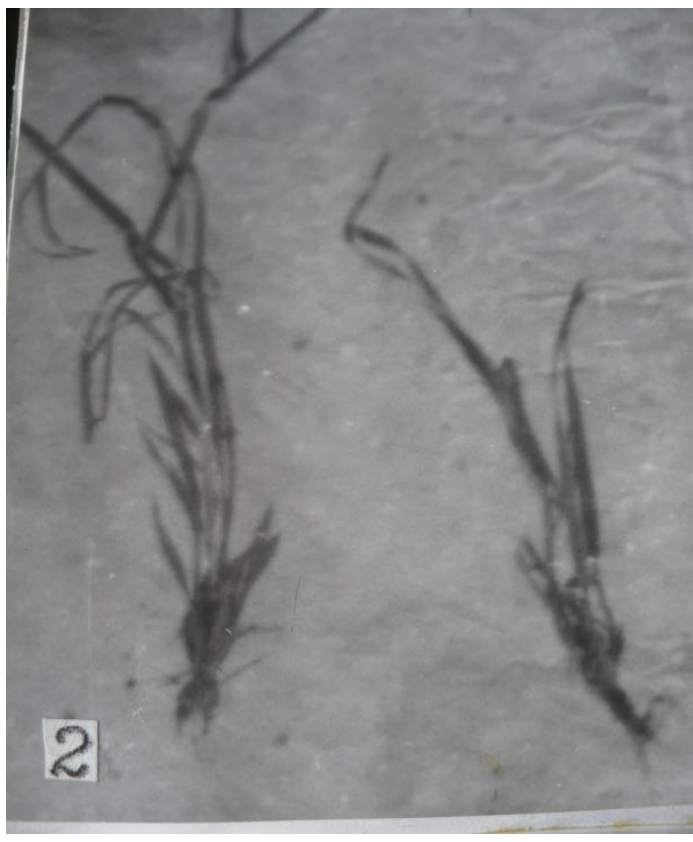

Овес

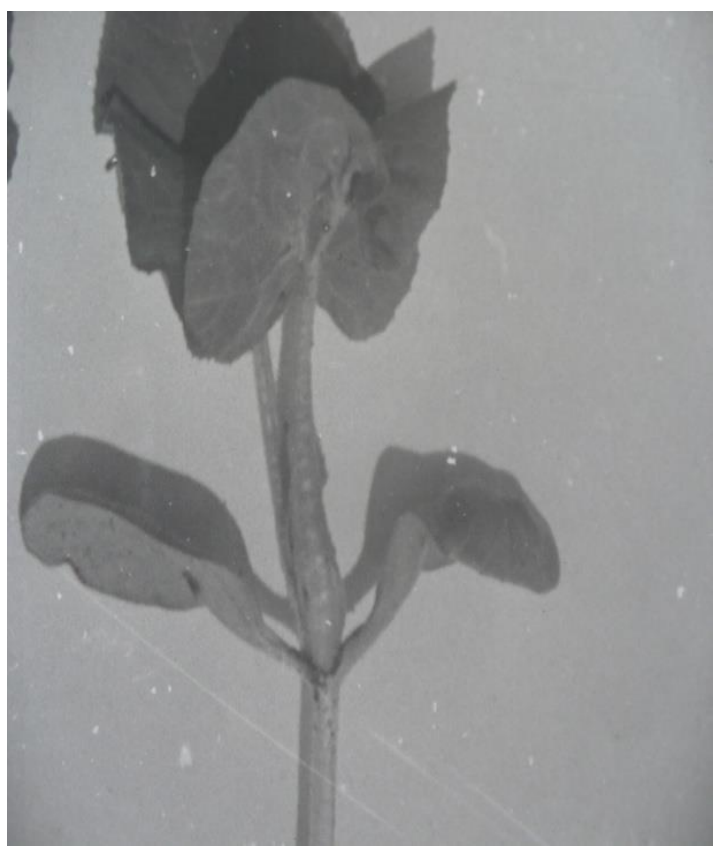

Кабачок

Рис. 1. Симптомы поражения различных видов растений при искусственном заражении земляничным дитиленхом 
Плодоводство и виноградарство Юга России № 50(02), 2018 г.

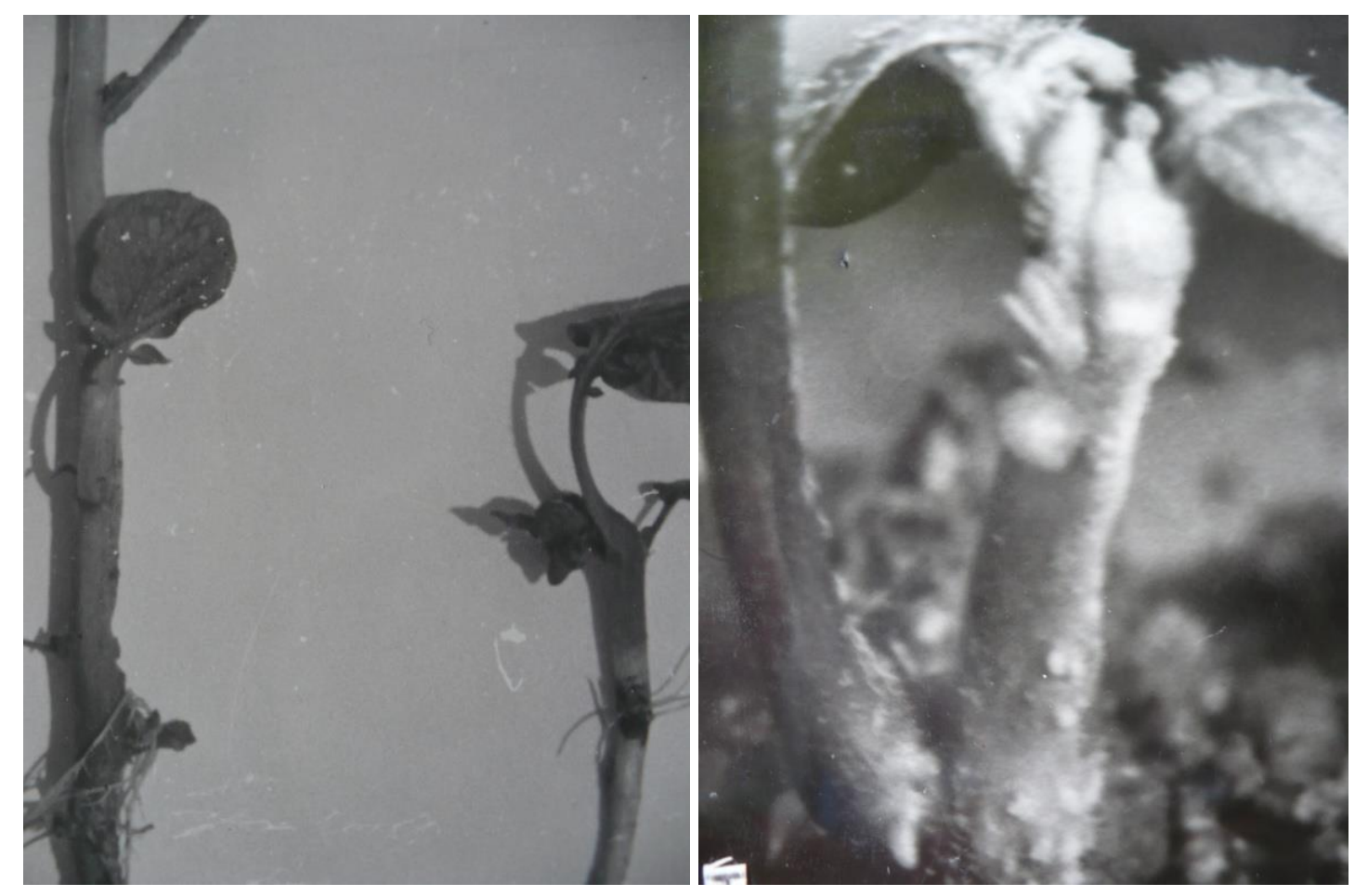

Картофель

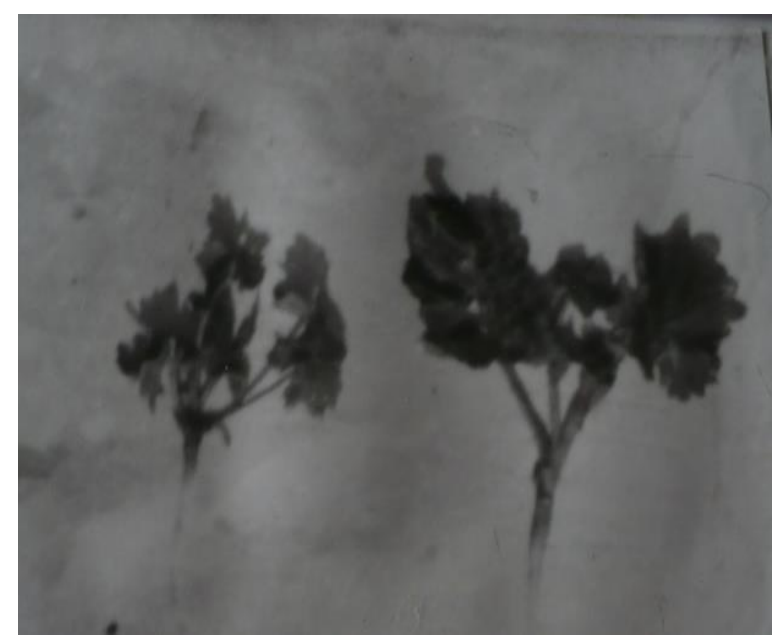

Пастернак

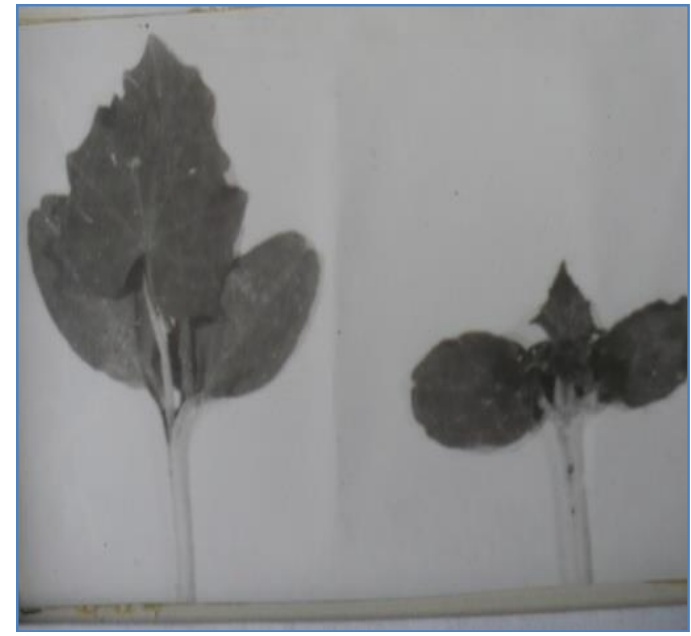

Огурец

Рис. 2. Симптомы поражения различных видов растений при искусственном заражении земляничным дитиленхом 


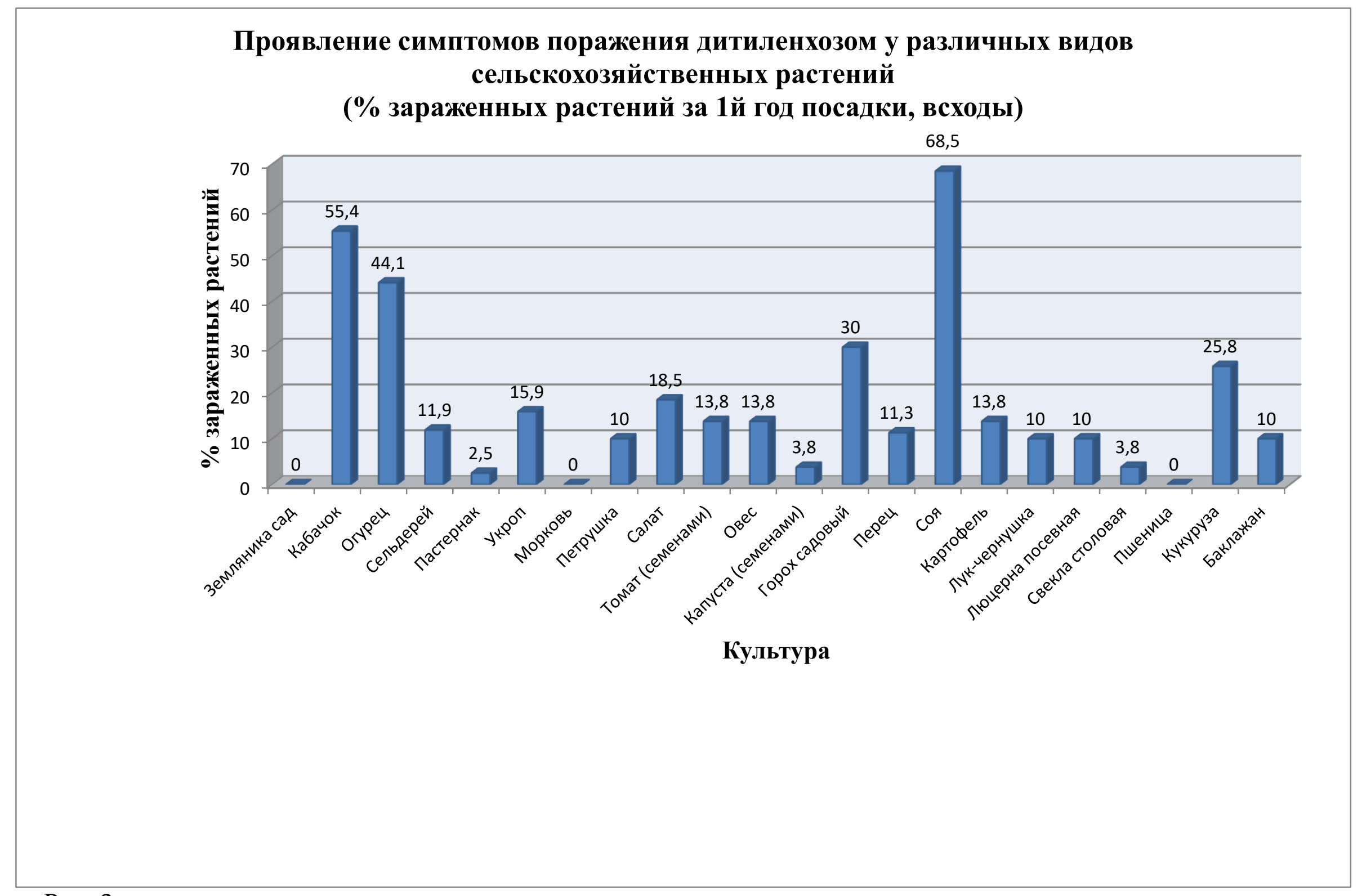

Рис. 3. 


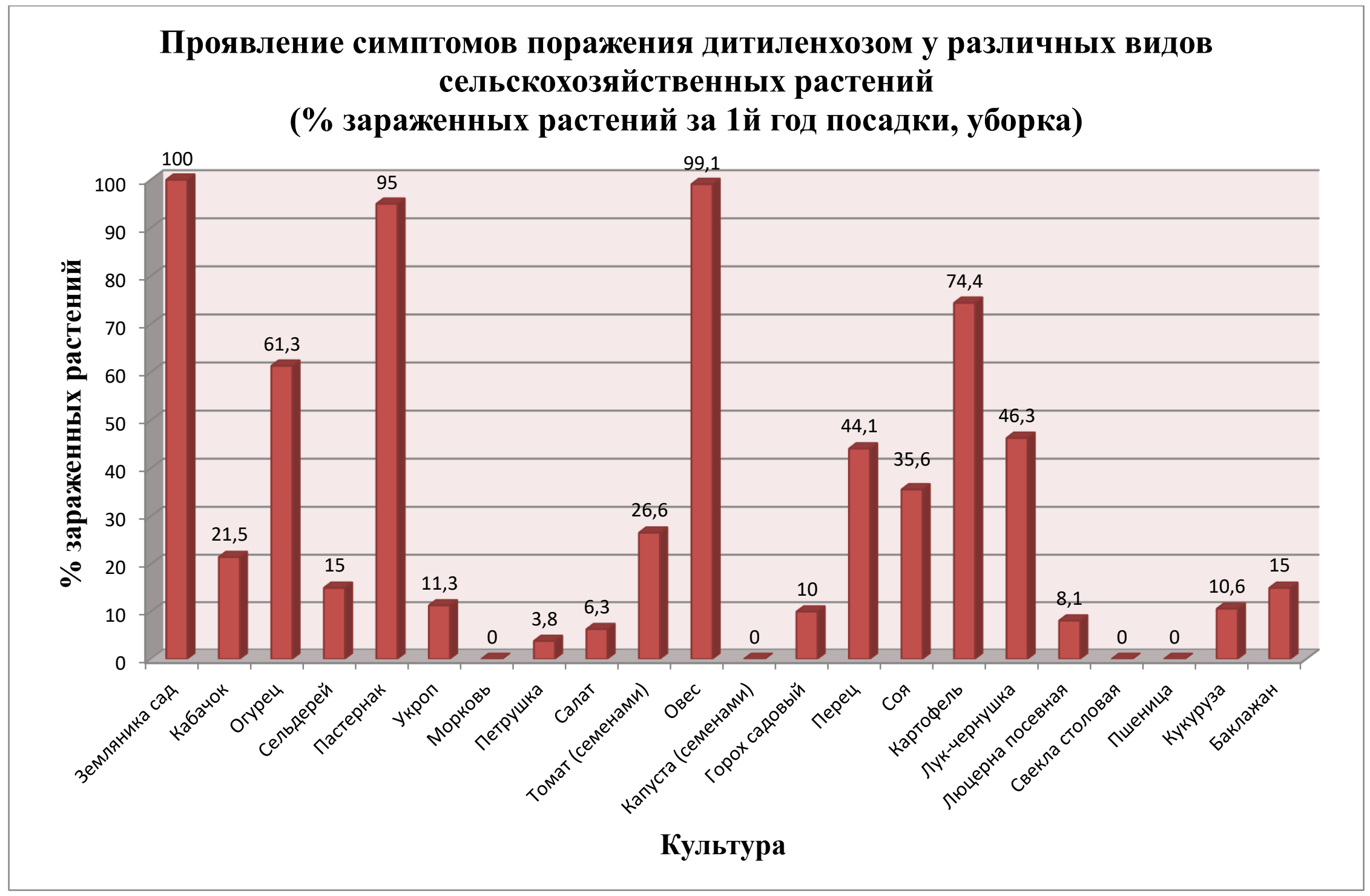

Рис. 4 


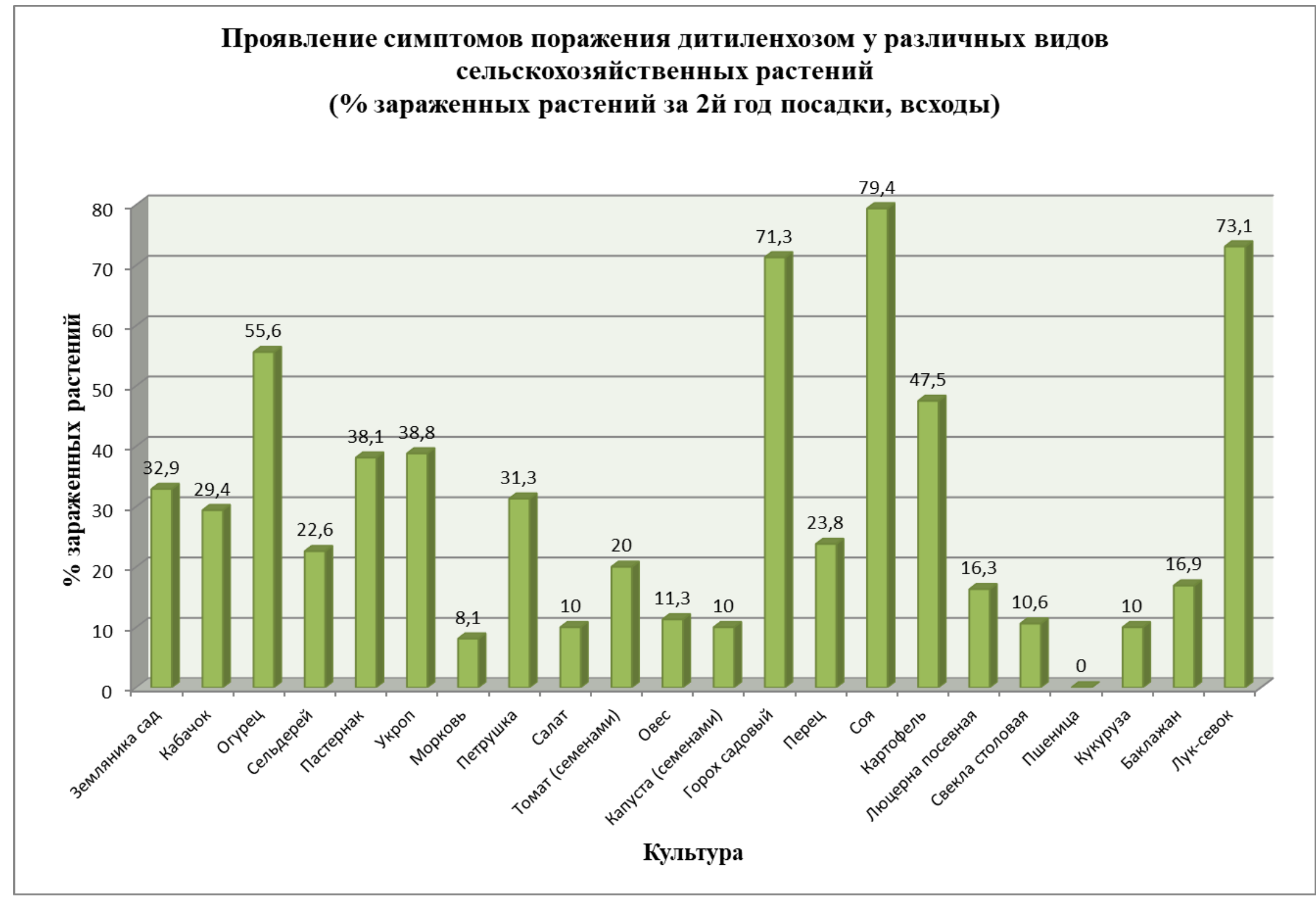

Рис. 5 


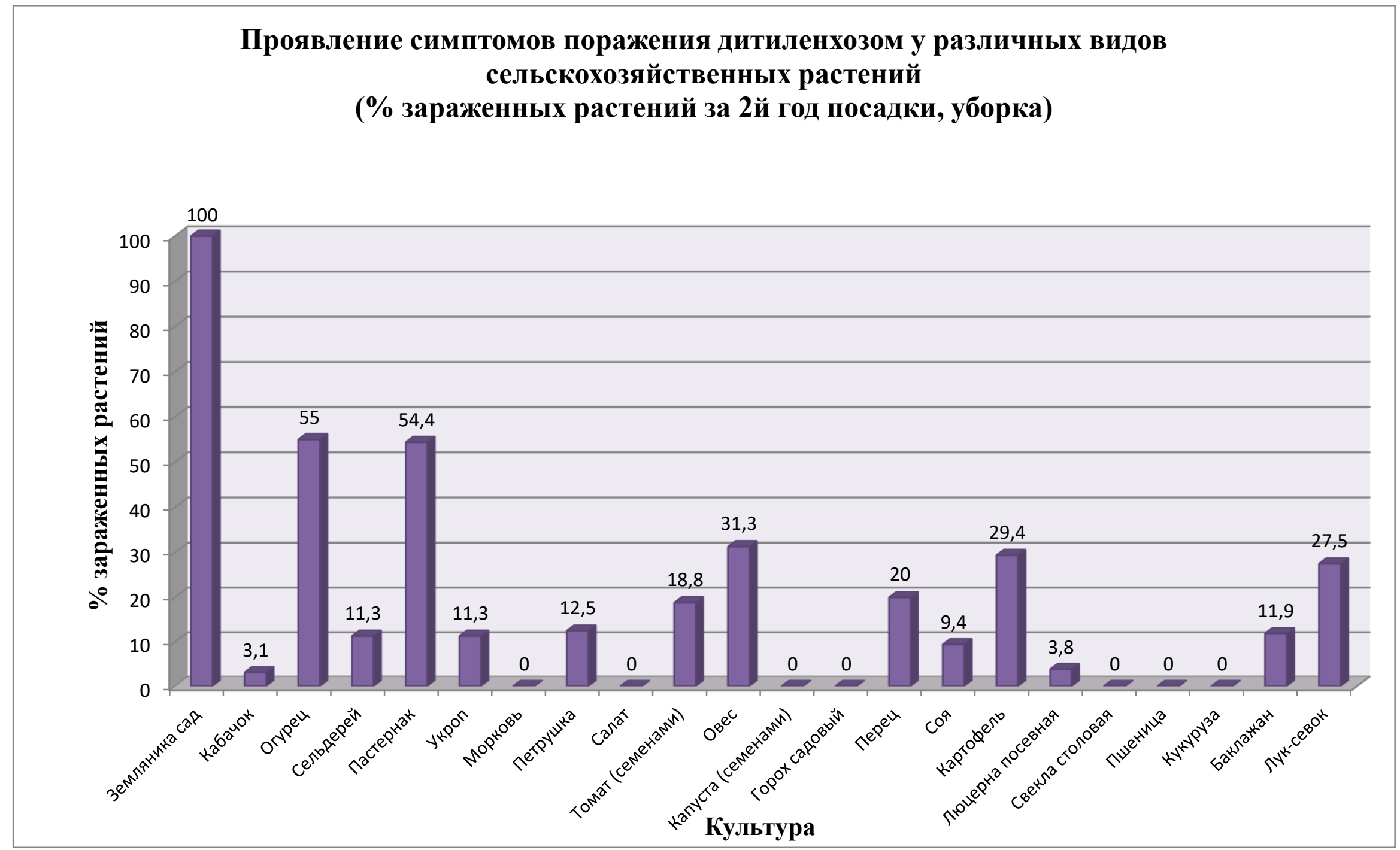

Рис. 6. 


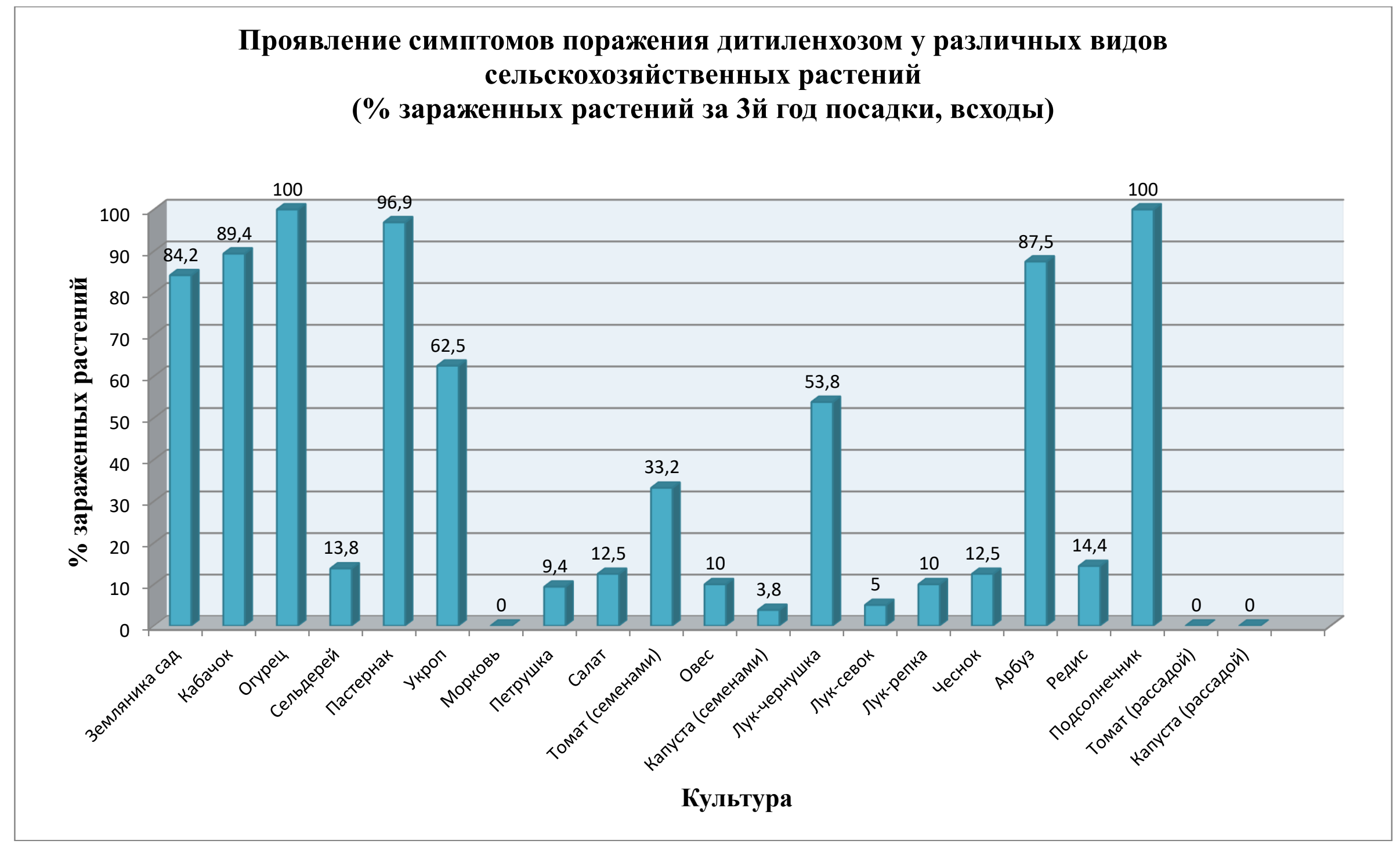

Рис. 7. 


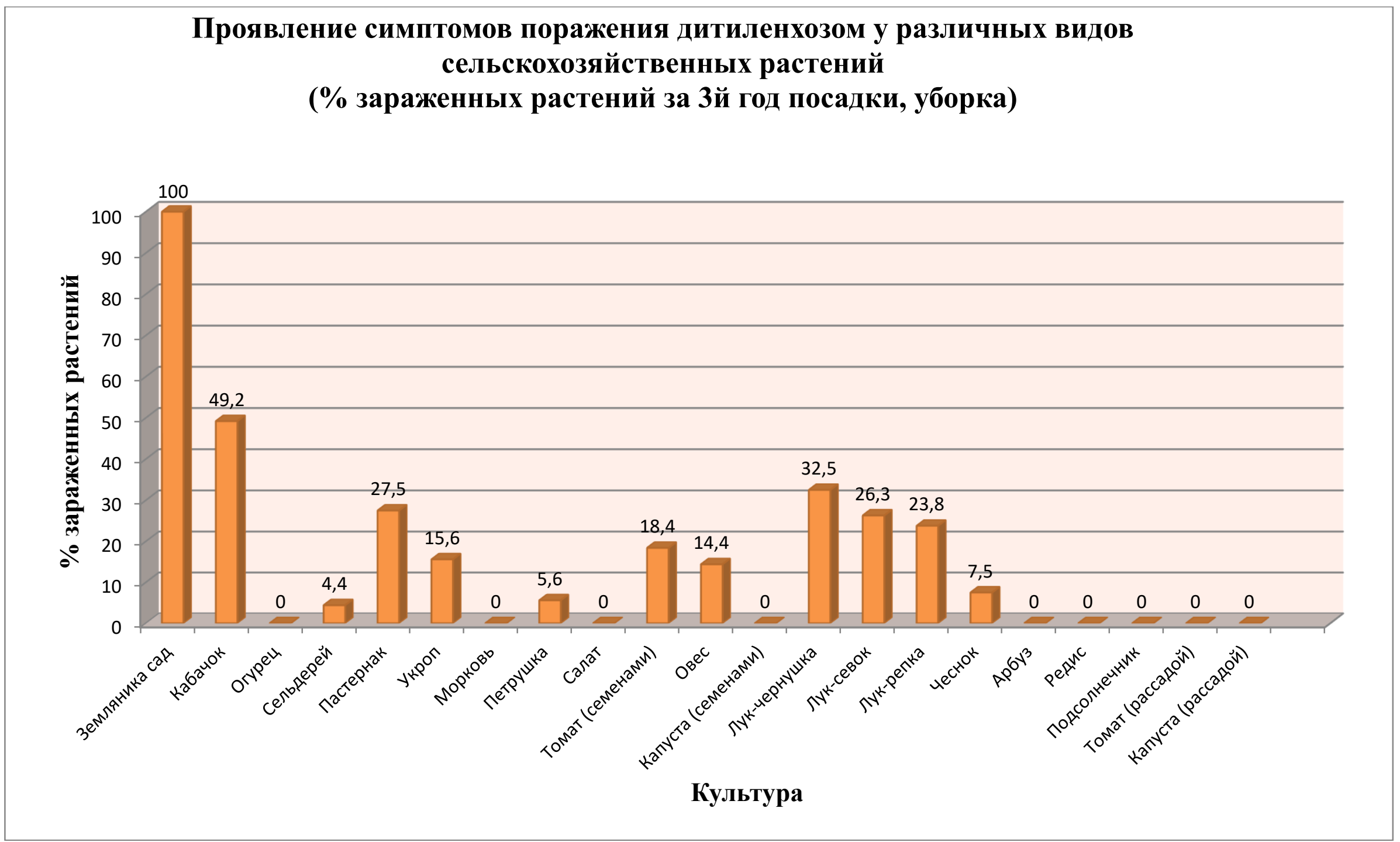

Рис. 8. 


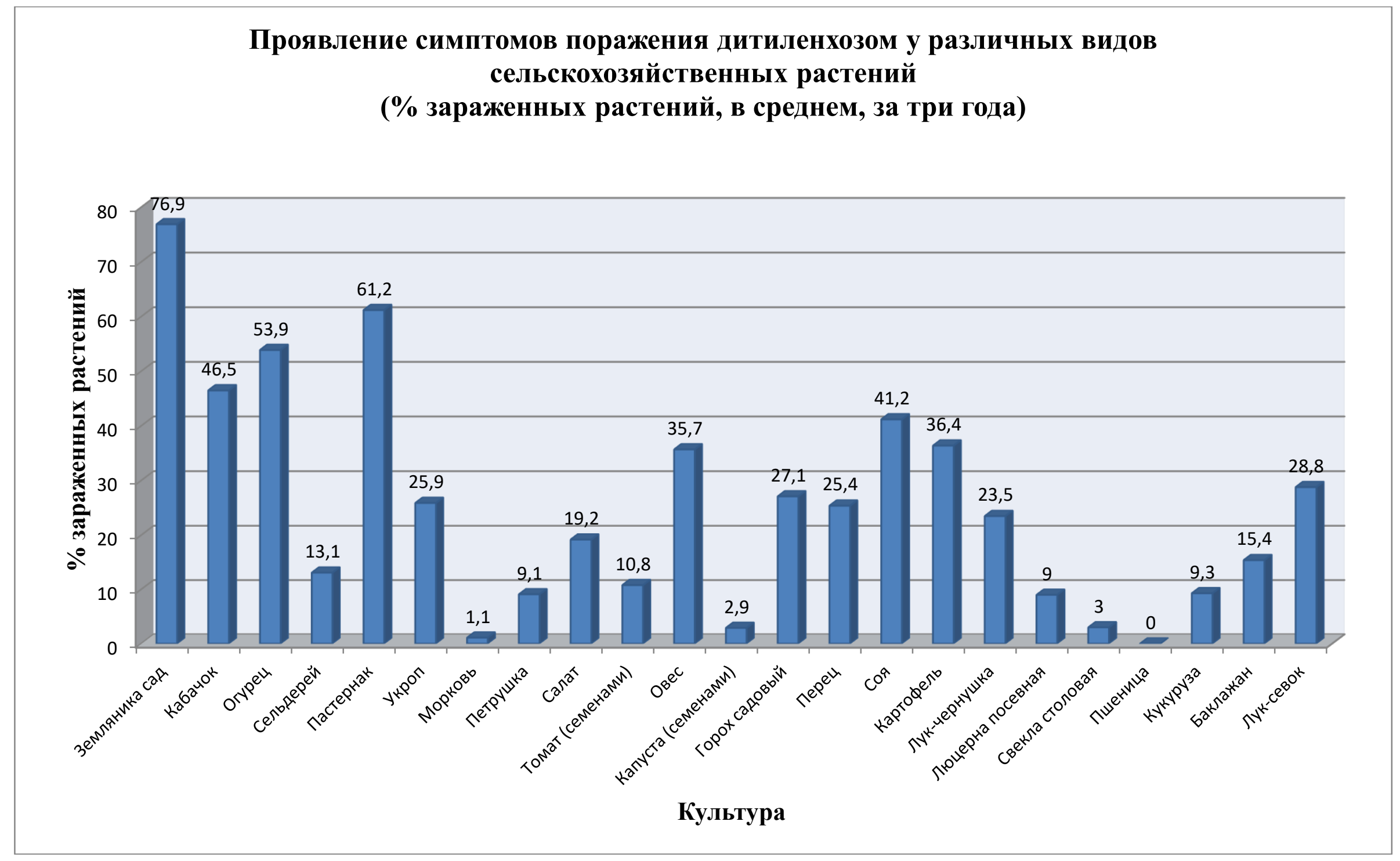

Рис. 9. 
Плодоводство и виноградарство Юга России № 50(02), 2018 г.

Следует добавить, что потери урожая существенно различались по годам. Они были наивысшими, когда опыт был заложен в конце мая-июне при температурах воздуха, достигавших $+32 \ldots+35^{\circ} \mathrm{C}$, и существенно ниже - при температурах до $+24 \ldots+27^{\circ} \mathrm{C}$. Очевидно, высокие температуры воздуха в начальный период развития ослабляют компенсационные возможности растений в сравнении с более низкими температурами. Кроме того, при высоких температурах $\left(+25^{\circ} \mathrm{C}\right)$ земляничный дитиленх существенно сильнее поражает, например, кукурузу, чем при более низких (до $\left.+20^{\circ} \mathrm{C}\right)[3,4]$.

Аналогичное явление отмечено и для ряда устойчивых к D. dipsaci copтов люцерны [15]. Земляничный дитиленх размножался помимо земляники садовой в луке, горохе, сое, салате (не во все годы), в картофеле (только при невысоких температурах и освещенности), овсе (при более высоких температурах) и, возможно, в 2-летних зонтичных растениях (пастернаке, петрушке, сельдерее). Во всех остальных случаях популяции паразита резко снижались, а нередко и полностью исчезали (в капусте, свекле, кукурузе, моркови, арбузе, редисе, подсолнечнике, в отдельные годы в огурце, салате).

Определенное влияние на результаты оценки могли оказать используемая методика и сроки учетов. Расчет плотностей популяций дитиленхов на 1 г растительной массы приводит к заниженным оценкам численности дитиленхов в растениях земляники, но может завышать их для мелких проростков других культур. Ткани многих растений при уборке высыхают и лигнифицируются, что лишает дитиленхов возможности питаться и размножаться, а поэтому снижается и их численность.

Как показали наши специальные наблюдения, на протяжении трех лет популяции дитиленхов достигают максимума в различных видах однолетних сельскохозяйственных растений через 6-8 недель после их инокуляции. Поэтому следует признать наиболее целесообразным проведение учета размножаемости дитиленхов в растениях именно в этот срок, как практикуют и за рубежом [16-19 и др.]. 
Плодоводство и виноградарство Юга России № 50(02), 2018 г.

В полевых условиях земляника садовая существенно превосходит другие виды сельскохозяйственных культур в способности поддерживать размножение земляничного дитиленха.

Наивысшие урожаи земляники были получены после выращивания пшеницы, свеклы столовой, огурца и капусты (в 5-6 раз выше, чем после наихудшего варианта - монокультуры земляники садовой). Сравнительно высокие урожаи были получены также после возделывания гороха, сои, моркови и люцерны. Низкие урожаи (но в 3 раза больше монокультуры земляники садовой) были отмечены после выращивания сельдерея, овса, петрушки, кабачка и томата.

Заключение. В условиях вегетационных и полевых опытов, на фоне естественного и искусственного заражения почвы земляничным дитиленхом, изучены реакции 29 видов сельскохозяйственных культур по степени поражения и влиянию на размножаемость D. dipsaci. Лук, гречиха, горох, овес, в несколько меньшей степени пасленовые и зонтичные (кроме моркови), оказались по восприимчивости к стеблевой нематоде близкими к землянике садовой по обоим показателям. Тыквенные, люцерна, клевер красный - не выносливыми культурами, но без поддержания размножения паразита. Пшеница, ячмень, кукуруза, свекла, капуста, морковь, редис проявили устойчивость к дитиленхозу, следовательно, они могут обеспечить реализацию продукционного и адаптивного потенциала земляники садовой.

\section{Литература}

1. Холод, Н.А. Фитосанитарное состояние змляничного агроценоза в условиях юга России / Н.А. Холод // Защита растений. - М., 2013, № 10 - С. 28-30.

2. Метлицкий, 0.3. Паразитические нематоды и основы борьбы с ними в ягодоводстве СССР: дис. ... д-ра с.-х. наук / Метлицкий Олег Зусьевич - М., 1979. - 515 с.

3. Холод, Н.А. Выявление и учет стеблевой нематоды / Н.А. Холод // Сб. науч. тр. Методика опытного дела и методические рекомендации СКЗНИИСиВ. Краснодар, 2002. $157 \mathrm{c}$. 
Плодоводство и виноградарство Юга России № 50(02), 2018 г.

4. Метлицкий, 0.3. Дитиленхоз садовой земляники Fragaria x ananassa Duch и меры борьбы с ним: дис. ... канд. биол. наук / Метлицкий Олег Зусьевич. - М., 1967. - 453 с.

5. Доспехов, Б.А. Методика полевого опыта / Б.А. Доспехов. - М.: Агропромиздат, 1985. $-351 \mathrm{c}$.

6. Ладыгина, Н.М. К сравнительной эколого-физиологической характеристике разных форм стеблевых нематод / Н.М. Ладыгина // Сб. науч. тр. НИИ биологии. Отдел фитогельминтологии и энтомологии. - Харьков. - 1970. - Вып. 39 (2). - С. 56-65.

7. Метлицкий, О.3. Методические указания по выявлению и учету паразитических нематод ягодных культур /О.З. Метлицкий, М.А. Матвеева, В.И. Андреева. - М., 1975. $39 \mathrm{c}$.

8. Метлицкий, О.З. К хозяинной специфичности земляничного и луково-чесночного дитиленхов / О.З. Метлицкий, Н.А. Холод // Сб. науч. тр. 10-й конф. Украин. о-ва паразитологов. - Киев, 1986. - Ч.2. - С. 26.

9. Холод, Н.А. Разработка элементов интегрированной защиты земляники от дитиленхоза в условиях Северного Кавказа: дис. ...канд. биол. наук : 03.00.20 / Холод Надежда Афанасьевна. - М., 1986. - 232 с.

10. Jones F.G.W. Aspects of plant nematology in GreatBritain//Agricultural Review, 1958. -Vol.3. -№ 12 -pp. 8 -19.

11. Кирьянова, Е.С. Паразитические нематоды растений и меры борьбы с ними / Е.С. Кирьянова, Э. Л. Кралль. - Л.,1971. - Т. 2. - 522 с.

12. Dewez W.J. Het optreden van het stengelaaltje (Tylenchus dipsaci) in Limburg // Tydschr. -Plziektcn, 1940. - J.46. - ss. 194-204.

13. Gentzsch D. Nematizidversuche ZUR Bekampfung des Stengelnematoden (Ditylenchus dipsaci) bei Speisezwiebeln. Berichte 13. «Probleme der Phytonematologie», Gross - Lusewitz, 1974. - ss. $73-78$.

14. Gentzsch D. Freilandgefassversuch uber den Einfluss der Pruchtfolge fur das Auftreten des Stengelnematoden (Ditylenchus dipsaci) bei Zwiebeln // 8. Vortragstagung zu aktuellen Problemen der Phytonematologie. - Rostock, 1983. - ss. 33 - 39.

15. Hirling W. Massnahmen und Versuche sur Bekampfung des Stengelalchens (Ditylenchus dipsaci) bei Erdbeeren // Pflanzenschutzdients Baden - Wurtemberg Jahresbericht fur, 1973, 1974. - ss. $40-50$.

16. Hesling J.J. Narcissus eelwom - yesterday and today // The Daffodil and Tulip Yearbook, 1966. - pp. $1-19$.

17. Sturhan D. Kreuzungsversuche mit biologischen Rassen des Stengelälchens (Ditylenchue dipsaci) // Nematologica, 1964. - Vol. 10. - № 2. - pp. 328-334.

18. Sturhan D. Vergleichende Wàrtspflanzenuntersuchungen an Stengelälchenn (Ditylenchue dipsaci) aus Rüben verschiedener Herkunft // Meded. Lendb. Hogesch. Gent., 1965. - Vol. 30. - № 3. - pp. 1468-1474.

19. Sturhan D. Studies on the inheritance of pathogenic and morphologic characteristics in the plant parasitic nematode Ditylenchus dipsaci // J. Parasitology, 1970. - Vol. 11. - pp. 474-475.

\section{References}

1. Holod, N.A. Fitosanitarnoe sostojanie zmljanichnogo agrocenoza v uslovijah juga Rossii / N.A. Holod // Zashhita rastenij. - M., 2013, № 10 - S. 28-30.

2. Metlickij, 0.3. Paraziticheskie nematody i osnovy bor'by s nimi v jagodovodstve CCCR: dis. ... d-ra s.-h. nauk / Metlickij Oleg Zus'evich - M., 1979. - 515 s. 
Плодоводство и виноградарство Юга России № 50(02), 2018 г.

3. Holod, N.A. Vyjavlenie i uchet steblevoj nematody / N.A. Holod // Sb. nauch. tr. Metodika opytnogo dela i metodicheskie rekomendacii SKZNIISiV. Krasnodar, 2002. - 157 s.

4. Metlickij, 0.3. Ditilenhoz sadovoj zemljaniki Fragaria x ananassa Duch i mery bor'by s nim: dis. ... kand. biol. nauk / Metlickij Oleg Zus'evich. - M., 1967. - 453 s.

5. Dospehov, B.A. Metodika polevogo opyta / B.A. Dospehov. - M.: Agropromizdat, 1985. $-351 \mathrm{~s}$.

6. Ladygina, N.M. K sravnitel'noj jekologo-fiziologicheskoj harakteristike raznyh form steblevyh nematod / N.M. Ladygina // Sb. nauch. tr. NII biologii. Otdel fitogel'mintologii i jentomologii. - Har'kov. - 1970. - Vyp. 39 (2). - S. 56-65.

7. Metlickij, O.Z. Metodicheskie ukazanija po vyjavleniju i uchetu paraziticheskih nematod jagodnyh kul'tur /O.Z. Metlickij, M.A. Matveeva, V.I. Andreeva. - M., 1975. - 39 s.

8. Metlickij, O.Z. K hozjainnoj specifichnosti zemljanichnogo i lukovo-chesnochnogo ditilenhov / O.Z. Metlickij, N.A. Holod // Sb. nauch. tr. 10-j konf. Ukrain. o-va parazitologov. Kiev, 1986. - Ch.2. - S. 26.

9. Holod, N.A. Razrabotka jelementov integrirovannoj zashhity zemljaniki ot ditilenhoza v uslovijah Severnogo Kavkaza: dis. ...kand. biol. nauk : 03.00.20 / Holod Nadezhda Afanas'evna. - M., 1986. - $232 \mathrm{~s}$.

10. Jones F.G.W. Aspects of plant nematology in Great Britain // Agricultural Review, 1958. - Vol. 3. - № 12. - pp. 8 - 19.

11. Kir'janova, E.S. Paraziticheskie nematody rastenij i mery bor'by $s$ nimi / E.S. Kir'janova, Je. L. Krall'. - L.,1971. - T. 2. - 522 s.

12. Dewez W.J. Het optreden van het stengelaaltje (Tylenchus dipsaci) in Limburg // Tydschr. -Plziektcn, 1940. - J.46. - ss. 194-204.

13. Gentzsch D. Nematizidversuche ZUR Bekampfung des Stengelnematoden (Ditylenchus dipsaci) bei Speisezwiebeln. Berichte 13. «Probleme der Phytonematologie», Gross - Lusewitz, 1974. - ss. 73 - 78.

14. Gentzsch D. Freilandgefassversuch uber den Einfluss der Pruchtfolge fur das Auftreten des Stengelnematoden (Ditylenchus dipsaci) bei Zwiebeln // 8. Vortragstagung zu aktuellen Problemen der Phytonema-tologie. - Rostock, 1983. - ss. 33 - 39.

15. Hirling W. Massnahmen und Versuche sur Bekampfung des Stengelalchens (Ditylenchus dipsaci) bei Erdbeeren // Pflanzenschutzdients Baden - Wurtemberg Jahresbericht fur, 1973, 1974. - ss. $40-50$.

16. Hesling J.J. Narcissus eelwom - yesterday and today // The Daffodil and Tulip Yearbook, 1966. - pp. $1-19$.

17. Sturhan D. Kreuzungsversuche mit biologischen Rassen des Stengelälchens (Ditylenchue dipsaci) // Nematologica, 1964. - Vol. 10. - № 2. - pp. 328-334.

18. Sturhan D. Vergleichende Wàrtspflanzenuntersuchungen an Stengelälchenn (Ditylenchue dipsaci) aus Rüben verschiedener Her-kunft // Meded. Lendb. Hogesch. Gent., 1965. - Vol. 30. - № 3. - pp. 1468-1474.

19. Sturhan D. Studies on the inheritance of pathogenic and morphologic characteristics in the plant parasitic nematode Ditylen-chus dipsaci // J. Parasitology, 1970. - Vol. 11. pp. 474-475. 